\title{
Aortic Endothelium of Alloxan Diabetic Rabbits: A Quantitative Study Using Scanning Electron Microscopy
}

\author{
V.V.Dolgov, O.E.Zaikina, M.F. Bondarenko and V.S. Repin \\ Central Institute of Advanced Medical Training, USSR Cardiology Research Centre AMS, Moscow, USSR
}

\begin{abstract}
Summary. Scanning electron microscope studies of the aorta and other major arteries have been performed in alloxan-induced diabetic rabbits. After 5 weeks, a variety of structural abnormalities of the endothelial lining were detected including a significant increase in the number of argyrophilic cells and an increased number of craters or openings in the endothelial junctional region. Evidence of more extensive micro-damage was present after 5 months duration of diabetes. These zones with structural changes in the endothelial lining of major vessels seem to be areas of high predilection to atherosclerosis in diabetes.
\end{abstract}

Key words: Aortic endothelium, alloxan diabetes, scanning electron microscopy, atherosclerosis, argyrophilic cells.

Macro- and microangiopathy are important complications in the diabetic. Microangiopathy has fairly well recognized characteristics, including endothelial proliferation and desquamation, together with capillary irregularity and closure and basement membrane thickening [1,2]. Macrovascular damage in diabetes is characterized by the initiation and rapid progression of early atherosclerosis [3, 4]. However, the mechanism of the primary damage to the aorta and other large vessels has not yet been fully elucidated.

Endothelial injury has been postulated as a potential initiating event in atherogenesis [5, 6]. It has also been proposed that damage to the endothelial layer may be an early pathological process in diabetes [7]. However, no experiments have been carried out to confirm this hypothesis, apart from one report [8], indicating that streptozotocin-induced diabetes in pigs caused irregularity and disruption of the endothelial surface.
We have used scanning electron microscopy for quantitative analysis of the main types of endothelial injury in experimental diabetes; using this method, large areas of endothelial luminal surface can be observed for the presence of micro-damage. The criteria for early endothelial injury are 1) number and size of zones of de-endothelialization, 2) presence of argyrophilic cells, 3) craters and openings on the cell surface and at intercellular junctions and 4) changes in the cell size [9-12].

\section{Materials and Methods}

Fifty-five chinchilla rabbits (body weight $3-4 \mathrm{~kg}$ ) were used. Diabetes was induced following IV injection of alloxan $(120 \mathrm{mg} / \mathrm{kg}$ body weight). Nine rabbits with 5 -week duration of diabetes and four with 5-month duration of diabetes were studied. Four rabbits with 5-week duration of diabetes received $0.8 \mathrm{U}$ protamine- $\mathrm{Zn}$-insulin $/ \mathrm{kg}$ body weight by daily injection for 4 weeks. The control group consisted of 21 animals of whom 17 were untreated. The vessels of two rabbits were examined $1 \mathrm{~h}$ after alloxan injection and compared with 2 animals who had failed to develop diabetes 5 weeks after alloxan treatment. A marked difference in the number of animals in each group was the result of a high mortality rate $(50 \%$ in 5 weeks and $67 \%$ in 5 months), due to the high toxicity of alloxan and in some instances due to uncontrolled severe diabetes.

\section{Levels of Hyperglycaemia and Hyperlipidaemia}

Blood samples were taken from ear veins in the morning following one day starvation. Blood glucose concentrations were determined using orthotoluidine and plasma cholesterol and triglyceride levels were measured using an autoanalyser (AA 11 Technicon). Insulin levels were determined by radioimmunoassay using a 'Sorin' testcollection of antisera. Blood insulin and glucose were measured in each animal before alloxan injection, on day 7 after alloxan administration and on the day of the experiment. In the group with 5month diabetes, blood glucose and insulin were measured monthly. Blood glucose of insulin-treated alloxan diabetic rabbits was measured before treatment and $23 \mathrm{~h}$ after each injection. If the glucose level remained higher than $7.2 \mathrm{mmol} / \mathrm{l}$, insulin $(1.2 \mathrm{U} / \mathrm{kg}$ body weight) was injected during the next 2 days. 
Table 1. Quantitative characteristics of endothelial cover in control and alloxan diabetic rabbits

\begin{tabular}{|c|c|c|c|c|c|c|c|c|c|c|}
\hline Group & Vessel & $\begin{array}{l}\text { Exam- } \\
\text { ined } \\
\text { area } \\
\left(\mathrm{mm}^{2}\right)\end{array}$ & $\mathrm{Cell} / \mathrm{mm}^{2}$ & $\begin{array}{l}\text { Longi- } \\
\text { tudinal } \\
\text { size } \\
(\mu \mathrm{m})\end{array}$ & $\begin{array}{l}\text { De-endo- } \\
\text { thelialized } \\
\text { area } \\
(\%)\end{array}$ & $\begin{array}{l}\text { No. of } \\
\text { de-endo- } \\
\text { thelialized } \\
\text { zones per } \mathrm{mm}^{2}\end{array}$ & Craters $/ \mathrm{mm}^{2}$ & $\begin{array}{l}\text { Argyro- } \\
\text { philic } \\
\text { cells } / \mathrm{mm}^{2}\end{array}$ & $\begin{array}{l}\text { Argyro- } \\
\text { philic } \\
\text { cells } \\
\text { area } \\
(\%)\end{array}$ & Stomata $/ \mathrm{mm}^{2}$ \\
\hline \multirow{3}{*}{$\begin{array}{l}\text { Control } \\
(\mathrm{n}=17)\end{array}$} & Thoracic aorta & 16.4 & $1340 \pm 50$ & $70 \pm 4$ & $0.004 \pm 0.004$ & $0.05 \pm 0.05$ & $2.0 \pm 1.2$ & $0.8 \pm 0.8$ & 0 & $3.8 \pm 1.6$ \\
\hline & Abdominal aorta & 56.4 & $1450 \pm 80$ & $74 \pm 2$ & $0.029 \pm 0.012$ & $0.29 \pm 0.11$ & $0.6 \pm 0.4$ & $1.0 \pm 0.5$ & 0 & $2.5 \pm 0.6$ \\
\hline & Carotid artery & 5.4 & $1780 \pm 100$ & $55 \pm 3$ & $0.016 \pm 0.015$ & $0.14 \pm 0.14$ & $0.6 \pm 0.6$ & $1.4 \pm 1.4$ & 0 & $4.5 \pm 1.5$ \\
\hline \multirow{3}{*}{$\begin{array}{l}\text { 5-week } \\
\text { diabetes } \\
(\mathrm{n}=9)\end{array}$} & Thoracic aorta & 19.8 & $1350 \pm 70$ & $72 \pm 4$ & $0.008 \pm 0.005$ & $0.16 \pm 0.11$ & $11.3 \pm 2.0^{\mathrm{a}}$ & $86 \pm 56^{\mathrm{a}}$ & 36.4 & $45.3 \pm 32.8$ \\
\hline & Abdominal aorta & 47.9 & $1340 \pm 50$ & $76 \pm 3$ & $0.018 \pm 0.008$ & $0.17 \pm 0.05$ & $26.6 \pm 3.8^{\sharp}$ & $124 \pm 57^{\mathrm{a}}$ & 32.4 & $19.6 \pm 5.8^{a}$ \\
\hline & Carotid artery & 22.5 & $1760 \pm 150$ & $66 \pm 2^{a}$ & $0.006 \pm 0.004$ & $0.12 \pm 0.08$ & $27.0 \pm 13.6^{\mathrm{a}}$ & $90 \pm 60^{2}$ & 31.2 & $31.2 \pm 8.6^{\mathrm{a}}$ \\
\hline \multirow{3}{*}{$\begin{array}{l}\text { 5-month } \\
\text { diabetes } \\
(n=4)\end{array}$} & Thoracic aorta & 36.0 & $1350 \pm 50$ & $71 \pm 5$ & $0.003 \pm 0.003$ & $0.07 \pm 0.07$ & $3.0 \pm 1.5$ & $13 \pm 10$ & 36.4 & $16.6 \pm 8.6$ \\
\hline & Abdominal aorta & 22.7 & $1370 \pm 40$ & $90 \pm 3^{a}$ & 0 & 0 & $9.2 \pm 3.6^{a}$ & $72 \pm 66$ & 11.9 & $18.2 \pm 6.3^{\mathrm{a}}$ \\
\hline & Carotid artery & 13.3 & $1360 \pm 50^{\mathrm{a}}$ & $79 \pm 5^{\mathrm{a}}$ & 0 & 0 & $7.8 \pm 6.1$ & $10 \pm 7$ & 8.3 & $16.2 \pm 4.2^{\mathrm{n}}$ \\
\hline \multirow{3}{*}{$\begin{array}{l}\text { Insulin- } \\
\text { treated } \\
\text { alloxan } \\
\text { diabetes } \\
(n=4)\end{array}$} & Thoracic aorta & 16.2 & $1370 \pm 100$ & $69 \pm 5$ & $0.020 \pm 0.012$ & $0.25 \pm 0.15$ & $4.0 \pm 2.1$ & $0.4 \pm 0.3$ & 0 & $3.3 \pm 0.9$ \\
\hline & Abdominal aorta & 16.2 & $1330 \pm 160$ & $84 \pm 7$ & $0.013 \pm 0.009$ & $0.12 \pm 0.06$ & $1.1 \pm 0.7$ & $3.8 \pm 3.8$ & 0 & $9.8 \pm 7.8$ \\
\hline & Carotic artery & 18.2 & $1450 \pm 110^{a}$ & $74 \pm 5^{\mathrm{a}}$ & $0.026 \pm 0.013$ & $0.30 \pm 0.08$ & $3.1 \pm 0.3^{a}$ & $4.7 \pm 1.9$ & $2 \pm 1$ & $7.4 \pm 2.1$ \\
\hline
\end{tabular}

Values are expressed as mean \pm SEM. ${ }^{\text {a }}$ Significant difference from control values $(\mathrm{p}<0.05)$ determined by $t-$ White criterion [16]

The experimental diabetic group consisted of those rabbits whose fasting blood glucose level was higher than $11 \mathrm{mmol} / 1$ one week after injection.

\section{Vessel Preparation for Scanning Electron Microscopy}

Rabbits were anaesthetized using nembutal and operated on using adequate artificial ventilation. The descending thoracic aorta, the abdominal aorta (from the coeliac artery to the aortic bifurcation) and the right carotid artery were cannulated and all branches were carefully ligated. The vessels were treated according to the method of Davies and Bowyer [13]: washed with Eagle's medium (3-5 min), rinsed with $5 \%$ glucose $(2-3 \mathrm{~min})$, impregnated with $0.1 \% \mathrm{Ag}$ $\mathrm{NO}_{3}(2 \mathrm{~min})$ and fixed with $2.5 \%$ glutaraldehyde $(12-15 \mathrm{~h})$ under a pressure of $1.33 \mathrm{kPa}$.

Fixed vessels were opened longitudinally, washed with water and then air-dried. Samples were coated with evaporated gold (thickness $30 \mathrm{~nm}$ ) and observed under a scanning electron microscope Jeol 35 at $25 \mathrm{kV}$ with $0.18 \mathrm{~mm}^{2}$ field and magnification $\times$ 200.

\section{Measurement of Area of Endothelial Injury: Calculation of the Number of Damaged Sites and Cell Shape Distribution}

Areas of endothelial damage were counted on each sample in 20-50 randomly chosen scanning fields. De-endothelialized areas were determined planimetrically. The number of argyrophilic cells, craters and openings were estimated in each field. The number and longitudinal size of cells were determined on photomicrographs of two random fields taken from each vessel. Regions lying close to the ostia were not taken into consideration, as artificial damage to the endothelial sheet may be observed frequently at such places.

\section{Study of Silver Distribution on Endothelial Luminal Surfaces by $X$-ray Microanalysis}

An X-ray dispersion spectrometer Kevex - 5100, linked to the scanning electron microscope, was used for studying the deposition of silver on the endothelial luminal surface. Samples observed primarily by scanning electron microscopy were located at a distance of $1.5 \mathrm{~cm}$ from the X-ray radiation detector at an angle of $40^{\circ}$. Suitable regions were chosen in a $5 \mu \mathrm{m}^{2}$ field and then calculated for $50 \mathrm{~s}$ at magnification $\times 10,000$. Each structure was examined by the spectrometer ten times. $X$-ray pulse height distribution was measured in the energy range of $0-10 \mathrm{keV}$ with a resolution of $10 \mathrm{eV}$. The area of the silver line peak $\mathrm{L}_{\alpha}$ in the energy interval $2.90-9.03 \mathrm{keV}$ was considered to be a characteristic signal. It was compared with the continuum signal taken simultaneously from the same sample in each spectrum in the energy interval $4.50-5.00 \mathrm{keV}$, in which no characteristic peaks were generated from the sample [14].

Signals obtained from the samples were compared with the standard signals for the quantitative analysis of silver distribution in morphological structures [15]. $\mathrm{AgNO}_{3}$ was used as a standard and the silver content under the area varied from 0.1 to $100 \mathrm{pg}$. The relationship between the silver content in the sample and characteristic/continuum ratios was linear for a constant scanning field.

\section{Results}

The weight loss of diabetic animals was $9 \%$ in 5 weeks and $26 \%$ in 5 months. Blood glucose concentration on the day of experiment, for the control group and for the 5-week and 5-month diabetes was $7.21 \pm 0.77$ (mean \pm SEM), $13.30 \pm 0.78(p<0.05)$, and $16.11 \pm$ $3.05 \mathrm{mmol} / 1(p<0.05)$, respectively, according to non-parametric t-White criteria [16]. Blood glucose levels oscillated from 11 to $20 \mathrm{mmol} / \mathrm{l}$ for the 5 -month duration of diabetes.

In the insulin-treated diabetic rabbits, blood glucose was $15.2 \pm 1.7 \mathrm{mmol} / 1$ before insulin administration falling to $6-10 \mathrm{mmol} / 1$ during insulin treatment. On the day of experiment, the blood glucose level was $8.50 \pm 0.52 \mathrm{mmol} / \mathrm{l}$, cholesterol $1.05 \pm$ 

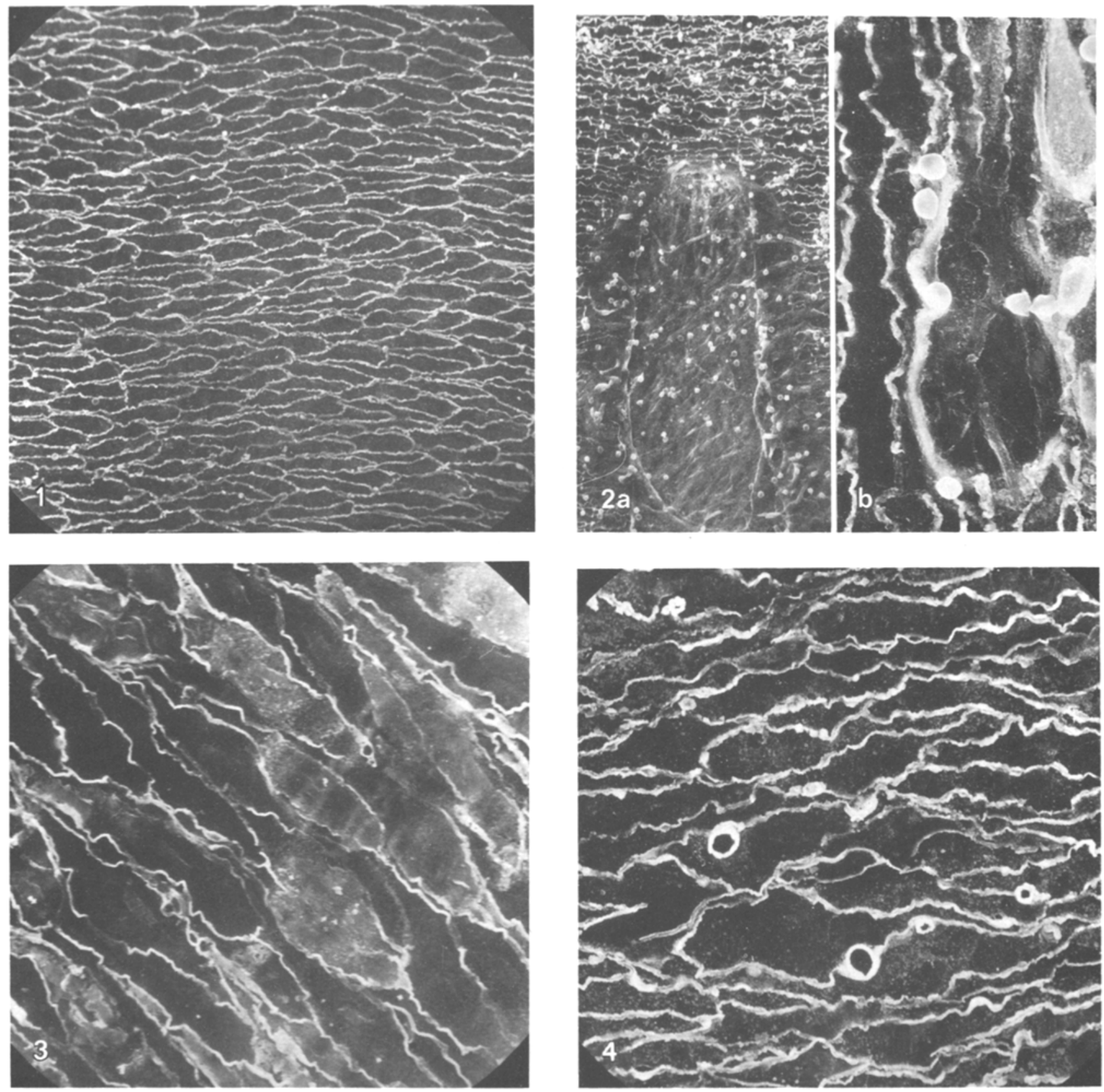

Fig. 1. The luminal surface of control rabbit thoracic aorta $(\times 200)$

Fig. 2 a and b. De-endothelialized areas in the normal rabbit aorta: a desquamation of the group cells $(\times 200), \mathbf{b}$ individual cell loss $(\times 1,000)$

Fig. 3. Argyrophilic cells on the luminal surface aorta from a rabbit of 5-week duration of diabetes $(\times 600)$

Fig.4. Craters on the luminal surface abdominal aorta from a rabbit of 5-week duration of diabetes $(\times 600)$

$0.27 \mathrm{mmol} / 1$ and triglyceride $0.42 \pm 0.05 \mathrm{mmol} / 1$. During oral glucose tolerance tests, blood glucose in this group increased from $8.50 \pm 0.63$ to $17.7 \pm$ $2.0 \mathrm{mmol} / \mathrm{l}$ (after $1 \mathrm{~h}$ ) and $10.7 \pm 1.7 \mathrm{mmol} / \mathrm{l}$ (after $3 \mathrm{~h})$. In the control non-diabetic rabbits, the blood glucose was $9.3 \pm 1.9($ after $1 \mathrm{~h})$ and $7.0 \pm 0.4 \mathrm{mmol} / 1$ (after $3 \mathrm{~h}$ ) after glucose loading.
Serum insulin concentration was $159 \pm 25$ (control group), $98 \pm 9$ (5-week diabetes, $p<0.05$ ) and 79 $\pm 19 \mathrm{pmol} / 1$ (5-month diabetes, $p<0.05)$; cholesterol concentration was $1.17 \pm 0.31,2.2 \pm 0.21(p<$ $0.05)$ and $2.0 \pm 0.26 \mathrm{mmol} / 1$ and triglyceride concentration was $0.38 \pm 0.03,0.61 \pm 0.08(p<0.05)$ and 1.1 $\pm 0.21 \mathrm{mmol} / 1(p<0.05)$, respectively. 

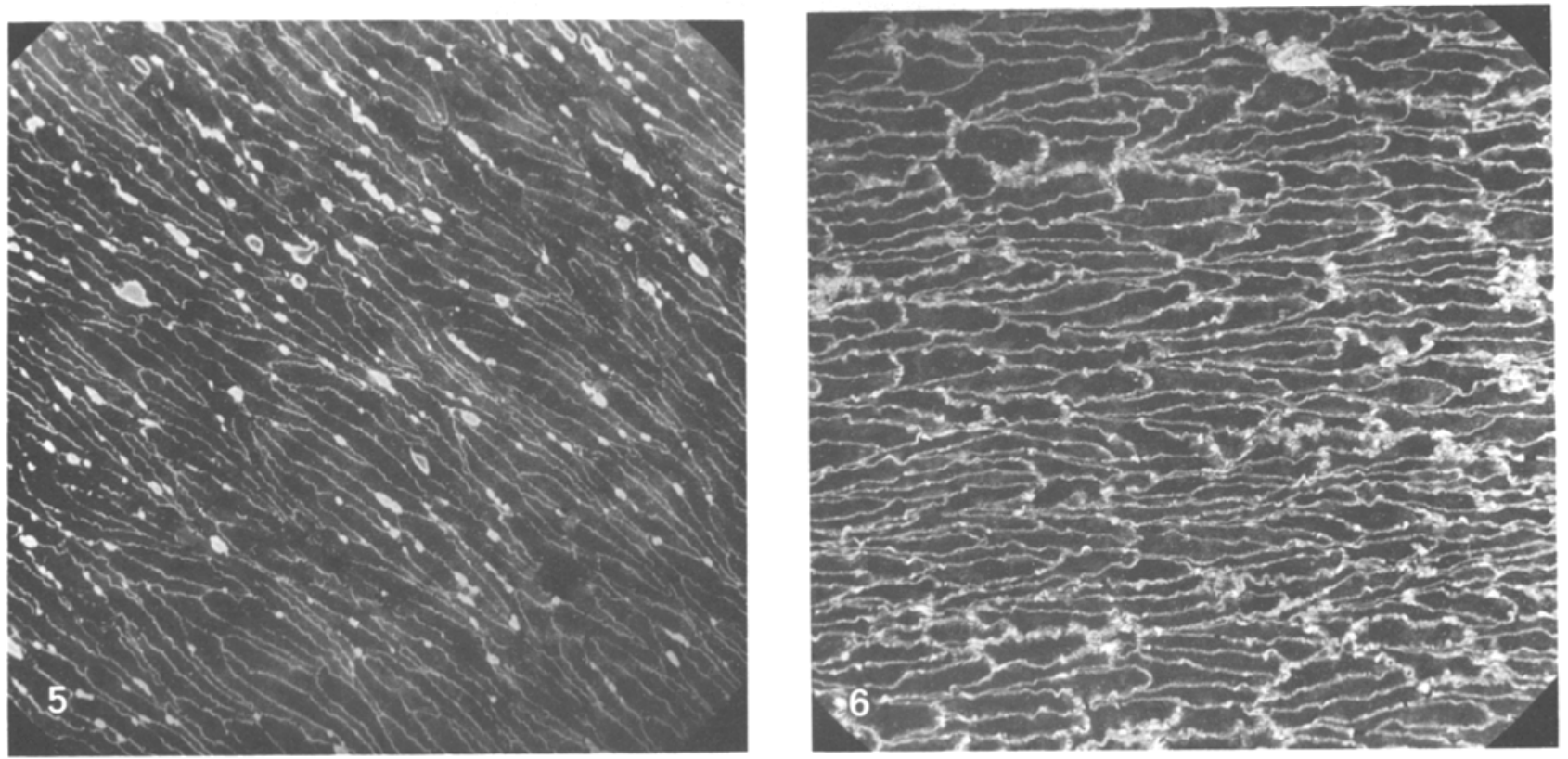

Fig.5. Argyrophilic stomata on the carotid artery luminal cover of a 5-week duration diabetic rabbit $(\times 200)$

Fig. 6. Intercellular boundary thickening on the thoracic aorta surface of a 5-month duration diabetic rabbit $(\times 200)$

\section{Control Group}

The luminal surface was lined by a continuous sheet of endothelial cells oriented along the axis of blood flow; only cell borders were uniformly stained with silver (Fig. 1). The density of monolayers (expressed as the number of cells $/ \mathrm{mm}^{2}$ ) was 1.3 times higher in the carotid artery, where smaller cells prevailed. Calculated cell sizes are in good agreement with the data obtained by the vascular casting technique [17], thus the fixation procedure used preserved the true endothelial cell size.

Spontaneous endothelial injury was found in some normal rabbits. Two main types of de-endothelialization were distinguished: desquamation of groups of cells (Fig. 2a) and of individual cells (Fig. 2b). The first type of de-endothelialization was rare and only one area of major endothelial cell loss with adherent platelets was found in an abnormal aorta amongst all the vessels examined. The second type of injury was seen with an average frequency of one per $6 \mathrm{~mm}^{2}$. No platelets adhered to these sites. The frequency of cell loss in the areas examined are shown in Table 1.

\section{5-Week Diabetes}

Cell density and sizes were unchanged except for an increase in cell length in the carotid artery. The number and areas of de-endothelialization zones in the examined vessels were not higher than in the control an- imals (Table 1). However, the number of argyrophilic cells was significantly higher in the thoracic aorta (107-fold increased), in the abdominal aorta (124-fold increased) and in the carotid artery (64-fold increased) (Table 1).

The regions of argyrophilic cells occupied approximately one-third of the examined area (Fig.2) and about ten argyrophilic cells were present in each scanning field. It was found that the number of argyrophilic cells was $13 \pm 3$ and $186 \pm 100$ per $\mathrm{mm}^{2}(p<$ 0.05 ) for rabbit subgroups with blood glucose concentration $<$ and $>13 \mathrm{mmol} / 1$ respectively. The frequency of craters per $\mathrm{mm}^{2}$ of endothelial luminal surface was also significantly increased (Fig.4): in the thoracic aorta (sixfold), in the abdominal aorta (44fold) and in the carotid artery (45-fold) (Table 1). In addition, the number of stomata was also significantly increased by 12.8 and sevenfold respectively (Table 1). The argyrophilic stomata are illustrated in Figure 5.

\section{5-Month Diabetes}

The number of cells per $\mathrm{mm}^{2}$ of the carotid artery luminal surface decreased by 1.3 -fold and the longitudinal size of endothelial cells increased by 1.2 -fold, and by 1.4 -fold in the carotid artery compared with normal rabbit. Intercellular boundary thickening was marked (Fig.6). The frequency of the other types of abnormality are shown in Table 2 . 
Table 2. Silver absorption by cells and craters on the luminal surface of vessels in control and alloxan diabetic rabbits

\begin{tabular}{|c|c|c|c|c|c|c|}
\hline \multirow[t]{2}{*}{ Group } & & \multicolumn{2}{|c|}{ Normal cells } & \multicolumn{2}{|c|}{ Argyrophilic cells } & \multirow[t]{2}{*}{ Craters } \\
\hline & & \multicolumn{2}{|c|}{ (pg per $5 \mu \mathrm{m}^{2}$ areas) } & \multicolumn{2}{|c|}{ (pg per $5 \mu \mathrm{m}^{2}$ areas) } & \\
\hline Control & $(n=10)$ & $1.8 \pm 0.1$ & $15.8 \pm 0.9$ & $22.6 \pm 3.1$ & $18.6 \pm 2.3$ & - \\
\hline Diabetes & $(n=10)$ & $1.7 \pm 0.1$ & $13.6 \pm 0.8$ & $14.8 \pm 2.2^{\mathrm{a}}$ & $19.3 \pm 3.0$ & $0.3 \pm 0.1$ \\
\hline
\end{tabular}

Results expressed as mean \pm SEM. ${ }^{\text {a }} p<0.05$ according to the Student's t-test

\section{Insulin-Treated Alloxan Diabetes}

No consistent morphological distinctions have been found in the thoracic and abdominal aorta of this group compared with the control animals (Table 1). However, in the carotid artery the cell density was decreased by 1.2 -fold, cell length was increased by 1.3 fold and the frequency of craters was higher by fivefold than normal.

\section{Quantitative Analysis of Silver Deposition}

$\mathrm{X}$-ray spectrometry was used for the study of silver topography on the luminal surface. The results are shown in Table 2. For the control group, the silver deposition at the borders of endothelial cells was ninefold higher than on their luminal surface. The amount of silver on the surface of argyrophilic cells was 12fold higher compared with the normal cell surface. The concentration of silver on the surface of argyrophilic cells was 1.2 times higher than at the cell borders. Minimal amounts of silver were detected on sub-endothelium at the sites of spontaneous de-endothelialization. These data show that there are significant differences in silver absorption by cells from normal and diabetic vessels.

\section{Discussion}

Diabetes is considered to be one of the risk factors for atherosclerosis [18]. According to Ross et al. [19, 20], the risk factors triggering or accelerating atherogenesis may cause primary injury to the endothelial sheet. It has been suggested that diabetes may accelerate the atherosclerotic process by injuring endothelial layers [7]. Certain methods for the quantitative analysis of endothelial damage have been developed recently. The most adequate method for the preservation of monolayer integrity in samples for scanning electron microscopy was reported by Davies and Bowyer [13] and has been used in this study.

The technique described made it possible to investigate the extent of injury and the morphological types of endothelial cell damage in the aorta and carotid artery of normal rabbits. Zones of large endothelial desquamation were not normally detected in healthy vessels, except for occasional sites of cell loss. This may reflect the natural endothelial turnover and is not accompanied by platelet adhesion.

Our studies have also shown that the frequency and area of de-endothelialization zones were equally small in both normal rabbits and in animals with 5week duration of diabetes. The apparent lack of deendothelialization may reflect some resistance to atherosclerosis in rabbits with alloxan diabetes [21, 22]. Therefore, this model is suitable for evaluating specific endothelial cell injury implicated only with diabetes.

The degree of argyrophilia represents a change in cell properties. The appearance of argyrophilic cells and stomata in diabetes is compatible with the concept of accelerated cell death and regeneration proposed by Vracko and Benditt [23]. The tendency to variable cell size in diabetes, especially in those animals with 5-month duration of diabetes, supports the idea of accelerated endothelial regeneration.

The possibility exists that an increased cellular uptake of silver in this animal model is secondary to the effect of alloxan injury which resembles endotoxininduced damage [9]. However, no changes were observed in the endothelial sheet of the aorta or in the carotid artery from rabbits examined either $1 \mathrm{~h}$ after alloxan injection or from rabbits resistant to alloxan 5 weeks after alloxan injection. These data suggest that there is no direct toxic effect of alloxan on the vascular endothelium. No consistent morphological changes of luminal surface have been observed in the thoracic and abdominal aorta in the group of insulintreated alloxan diabetic rabbits. This observation indicates that the structural changes of the endothelial cover were, in fact, attributable to the diabetes.

In our studies, we found that there is a significant increase in argyrophilic cells in diabetic animals, particularly after 5-week duration of diabetes, showing phasic process. Recently we have found phasic structural changes of endothelial integrity in rabbit aorta and carotid artery, during early stages of experimen- 
tal hypercholesterolaemia [24]. The presence of craters, as has been suggested previously [25], occurs as the result of weakening of intercellular junctions. This weakening results in the appearance of smooth muscle cell pseudopodia, which extrude from the media through holes of the elastic membranes and at sites of damaged endothelial junctions. Following fixation of the tissues, these myointimal hernia are destroyed and craters are formed. A significant increase of craters was observed in the endothelial sheet of the aorta in most of our diabetic animals.

High blood glucose concentration may exert direct cytotoxic effect on the endothelial cells [26, 27]. Increased glucose concentration resulted in an accumulation of sorbitol in the rabbit aorta [28] via the polyol pathway. This excess can lead to aorta intimamedia swelling and impaired oxygen diffusion.

In summary, diabetes associated with hypoinsulinaemia, is accompanied by primary damage to the endothelial sheet of macro-vessels. These regions with structural abnormalities may be zones of high predilection to atherosclerosis in diabetes.

\section{References}

1. Blumental HT, Alex M, Goldenberg S (1960) A study of lesions of the intramural coronary artery branches in diabetes mellitus. Arch Pathol 70: 27-42

2. Ravid M, Silman-Socher R, Ben Shaul J, Sorah E (1976) Quantitative electron microscopic study of capillaries in diabetes mellitus. Beitr Pathol 159:280-291

3. Stocks AE (1976) Vascular problems of diabetes. Presentation and management. Med J Aust 2: 540-543

4. Levine R (1978) Role of hyperglycaemia in the progression of diabetic vascular disease. West J Med 129: 231-233

5. Ross R, Glomset J, Kariya B, Herker L (1974) A platelet-dependent serum factor that stimulates the proliferation of arterial smooth muscle cells in vivo. Proc Nat Acad Sci 71:1207-1210

6. Ross R (1976) Atherosclerosis: the role of endothelial injury, smooth muscle cell proliferation and platelet factors. Triangle $15: 45-51$

7. Bierman EL, Brunzell JD (1978) Interrelation of atherosclerosis, abnormal lipid metabolism and diabetes mellitus. In: Katzen HM, Mahler RJ (eds) Advances in modern nutrition, vol. 2. Hemisphere Publishing Corporation, Washington, London. pp 187-210

8. Marshall M (1980) Experimental and clinical results concerning regression of atherosclerosis. Folia Angiol 28: 80-84

9. Reidy MA, Bowyer DE (1977) Scanning electron microscopy: morphology of aortic endothelium following injury by endotoxin and during subsequent repair. Atherosclerosis 26: $319-328$

10. Goode TB, Davies PF, Raidy MA, Bowyer DE (1977) Aortic endothelial cell morphology observed in situ by scanning electron microscopy during atherogenesis in the rabbit. Atherosclerosis 27: $235-251$

11. Buss H, Hollweg HG (1977) Scanning electron microscopy of blood vessels: a review. Scan Electron Micros 2: 467-476
12. Nelson E, Gertz SD, Forbes MS, Rennels ML, Heald FP, Kahn MA, Farbert TM, Miller E, Husain HH, Earl FP (1976) Endothelial lesions in the aorta of egg yolk-fed immature swine: a study by scanning and transmission electron microscopy. Exp Mol Pathol 25: 208-220

13. Davies PF, Bowyer DE (1975) Scanning electron microscopy: arterial endothelial integrity after fixation at physiological pressure. Atherosclerosis 21: $463-466$

14. Cameron IL, Smith KR, Pool TB (1979) Element concentration changes in mitotically active and postmitotic enterocytes. An X-ray microanalysis study. J Cell Biol 80: 444-450

15. Hall TA, Anderson HC, Appleton T (1973) The use of thin specimens for X-ray microanalysis in biology. J Microsc 99: 177-182

16. Lakin HF (1980) Non-parametric criterion. In: Deryabin VE (ed), Biometria. Visshay shkola, Moscow, pp 110-116

17. Cornhill JF, Levesque MJ, Herderick EE, Nerem RM, Kilman JW, Vasco JS (1980) Quantitative study of the rabbit aortic endothelium using vascular casts. Atherosclerosis 35:321-337

18. Kannel WB, McGee DL (1979) Diabetes and cardiovascular disease. The Framingham study. JAMA 241: 2035-2038

19. Ross R, Glomset J (1976) The pathogenesis of atherosclerosis. N Engl J Med 295: 369-377

20. Bierman EL, Ross R (1977) Aging and atherosclerosis. In: Paoletti R, Gotto AM (eds) Atherosclerosis reviews, vol.2. Raven Press, New York, pp 79-111

21. Duff GL, McMillan GC (1949) The effect of alloxan diabetes on experimental cholesterol atherosclerosis in the rabbit. J Exp Med 89:611-630

22. Cook DL, Milles LM, Green DM (1954) The mechanism of alloxan protection in experimental atherosclerosis. J Exp Med 99: $119-124$

23. Vracko R, Benditt EP (1974) Manifestations of diabetes mellitus. Their possible relationship to an underlying cell defect. Am J Pathol 75:204-224

24. Zaikina OE, Dolgov VV, Ivanov VN, Bondarenko MF, Repin VS (1982) Quantitative SEM analysis of injury to the endothelium of rabbit aorta and carotid artery during experimental atherosclerosis. Atherosclerosis 41: 141-154

25. Stetz EM, Majno G, Joris I (1979) Cellular pathology of the rat aorta. Pseudovascuoles and mio-endothelial herniae. Virchows Arch [Pathol Anat] 383: 135-148

26. Ostrander LD, Francis T, Hayner NS, Kjelsberg MO, Epstein FH (1965) The relationship of cardiovascular disease to hyperglycemia. Ann Intern Med 62: 1188-1198

27. Duhault J, Bure J, Lochampt MO, Beert L, Regnault F, Sicot N, Boulanger M (1979) The effect of high glucose concentration on the proliferation and the synthesis of lipids in endothelial cells in culture. Biomedicine $30: 56-60$

28. Morrison AD, Orci L, Perrelet A, Winegrad L (1979) Studies of the effects of an elevated glucose concentration on the ultrastructure and composite metabolism of the intact rabbit aortic intima-media preparation. Diabetes 28:720-723

Received: 15 January 1981

and in revised form: 10 December 1981

Dr. V.V. Dolgov

Second Botkinski proezd 7

Chair of Pathophysiology

Central Institute of Advanced Medical Training

Moscow 125284, USSR 